\title{
IŠEMINĖS ŠIRDIES LIGOS IR SAVIŽUDYBIŲ PAPLITIMO SĄSAJA EUROPOS SĄJUNGOJE
}

\author{
Petras Navickas $^{1,2}$, Laura Lukavičiūtè ${ }^{1,2}$, Pranas Šerpytis ${ }^{1,2}$, Alvydas Benošis ${ }^{4}$, \\ Rokas Šerpytis ${ }^{1,2}$, Konstantinas Daškevičius ${ }^{5}$, Alvydas Navickas ${ }^{1,3}$ \\ ${ }^{1}$ Vilniaus universiteto Medicinos fakultetas, ${ }^{2}$ Vilniaus universiteto ligonine Santaros klinikos, \\ ${ }^{3}$ Vilniaus universiteto Medicinos fakulteto Psichiatrijos klinika, \\ ${ }^{4}$ Valstybine teismo medicinos tarnyba, ${ }^{5}$ Nepriklausoma teismo psichiatrijos tarnyba
}

Raktažodžiai: išeminė širdies liga, savižudybès, Europos Sajunga, lytis, amžius.

\begin{abstract}
Santrauka
Darbo tikslas. Ivertinti mirtingumo dèl kraujotakos sistemos ligų ir savižudybių ryšį Europos Sajungos (toliau - ES) valstybèse.

Darbo metodika. Atliktas epidemiologinis analitinis mirtingumo dèl išeminès širdies ligos (I20-I25, TLK10AM) bei kitų širdies ligų formų (I30-I52, TLK10AM) ir mirtingumo dèl savižudybių (X60-X84, TLK-10AM) tyrimas. Atlikta analizè apėmé 1994 - 2015 metų standartizuotus duomenis iš 30 (ES28, Norvegija, Šveicarija) Europos valstybių. Duomenys taip pat vertinti pagal amžiaus grupes: $<65$ metų bei $\geq 65$ metų ir pagal lyti.

Rezultatai. Mirtingumas dẻl išeminès širdies ligos ir savižudybių statistiškai reikšmingai tiesiogiai koreliavo 23 valstybėse: 9 - labai stipriai; 7 - stipriai; 4 - vidutiniškai ir 3 - silpnai. Vyrų rodikliai reikšmingai koreliavo taip pat 23 valstybèse: 8 - labai stipriai; 10 - stipriai; 3 - vidutiniškai ir 2 - silpnai. Moterų rodikliai - 19 valstybių: 4 - labai stipriai; 9 - stipriai ir 6 - vidutiniškai. Iki 65 metų amžiaus grupeje mirtingumas reikšmingai tiesiogiai koreliavo 23 valstybėse: 7 - labai stipriai; 9 - stipriai; 4 - vidutiniškai ir 3 - silpnai, o $\geq 65$ metu amžiaus grupeje reikšmingai tiesiogiai koreliavo 21 valstybèse: 6 - labai stipriai; 9 - stipriai; 5 - vidutiniškai ir 1 - silpnai. Lietuvoje šis ryšys buvo reikšmingas tarp abiejų lyčių (Rho: bendrai-0,798, $\mathrm{p} \leq 0,001$; vyrai- $0,717, p \leq 0,001$; moterys $-0,799, p \leq 0,001$ ) bei amžiaus grupių ( $<65$ metų: bendrai- $-0,462, p=0,03$; vyrai- $0,489, p=0,021 ;$ moterys $-0,385, p=0,077 ; \geq 65$ metų: bendrai- $0,814, p \leq 0,001$; vyrai- $0,638, p=0,001$;
\end{abstract}

moterys-0,785, p $\leq 0,001)$. Pabrèžtina, kad analizuojant ryši tarp mirtingumo dèl kitų širdies ligų ir dèl savižudybių nustatytas ženkliai silpnesnis tiesioginis ryšys: reikšminga tiesiogine koreliacija stebèta 13 valstybių, tarp vyrų -12 , tarp moterų -9 , o priešingas ryšys nustatytas netgi 7 valstybèse.

Išvados. Nustatytas reikšmingas tiesioginis ryšys tarp mirtingumo dẻl išeminès širdies ligos ir savižudybių daugelyje Europos Sajungos valstybių bei išlieka reikšmingas tiek tarp vyrų ir moterų bei asmenų, jaunesnių ir vyresnių nei 65 metai. Tikètina, kad psichinès sveikatos įtaka šioms dviem problemoms yra labai reikšminga. Ypač Lietuvoje šiu problemų didžiulis mastas ir jų reikšmingas ryšys reikalauja efektyvesnių psichinès sveikatos priežiūros metodų plètros.

\section{İvadas}

Kraujotakos sistemos ligos yra viena iš pagrindinių mirštamumo priežasčių visose Europos Sajungos (toliau - ES) valstybėse: jos sudaro nuo 50 proc. iki 60 proc. visų mirčių Baltijos šalių regione, Rumunijoje bei Bulgarijoje ir mažiau nei ketvirtadalị mirčių Danijoje (24,0 proc.) ir Prancūzijoje (24,5 proc.) [1]. Lietuvoje per pastaraji penkmetị (2013 2017 metai) dèl kraujotakos sistemos ligų nustatyta daugiau kaip 115 tūkstančių mirties atvejų, kas sudarè 56,2 proc. visų mirčių atvejų [2]. Didžiają dalį šių mirčių (65,3 proc.) sudaré mirtingumas dèl išeminès širdies ligos. Taip pat Lietuvoje stebimas didžiausias Europoje ir vienas didžiausių visame pasaulyje savižudybių dažnis [3]. Irodyta, jog savižudybių problema glaudžiai susijusi su įvairiais psichikos sutrikimais [4], o psichikos sveikata turi nenuginčijamą ittaką išeminès širdies ligos vystymuisi [5].

Darbo tikslas: ịvertinti mirtingumo dèl kraujotakos sistemos ligų ir savižudybių ryšį Europos Sajungos (toliau - ES) valstybèse. 


\section{Tyrimo objektas ir metodai}

Atliktas epidemiologinis analitinis mirtingumo dèl išeminès širdies ligos bei kitų širdies ligų formų ir mirtingumo dèl savižudybių tyrimas. Naudoti mirties atvejų ir priežasčių valstybès registro bei „Eurostat“ bazių duomenys. Atlikta analizè apėmè 28 Europos Sajungos valstybių ir Norvegijos bei Šveicarijos duomenis. Atlikta 1994 - 2015 metų standartizuotų pagal Europos amžiaus standartą (1976 m.) mirtingumo dèl tyčinių susižalojimų (X60-X84, TLK-10AM) ir išeminès širdies ligos (I20-I25, TLK-10AM) bei kitų širdies ligų formų (I30-I52, TLK-10AM) rodiklių 100000 gyventojų analizè. Duomenys taip pat vertinti išskirsčius tiriamuosius i amžiaus grupes $<65$ metų bei $\geq 65$ metų ir pagal lytį.

Tyrimo duomenų analizè atlikta naudojant statistinès analizès paketą SPSS (angl. Statistical Package for Social sciences, IBM Corp., versija 21.0). Analizuojamų mirtingumo tarpusavio duomenų ryšiui vertinti panaudotas Spirmeno (Spearman) koreliacijos koeficientas (Rho). Buvo vertinta, jog ryšys abejotinas, jeigu Rho buvo $0-0,29$; silpnas, jeigu Rho 0,3-0,49; vidutinio stiprumo, kai 0,5-0,69; stiprus, kai 0,7-0,89; ir labai stiprus, kai Rho 0,9-1. Vertinome, jog ryšys tarp lyginamųjų grupių yra statistiškai patikimas, kai reikšmingumo lygmuo $\mathrm{p}<0,05$.

\section{Rezultatai}

Mirtingumas nuo išeminės širdies ligos ir savižudybiu statistiškai reikšmingai tiesiogiai koreliavo 23 valstybėse (1 lentelè, 1 paveikslas): 9 - labai stipriai; 7 - stipriai; 4 - vidutiniškai ir 3 - silpnai. Vyrų rodikliai statistiškai reikšmingai

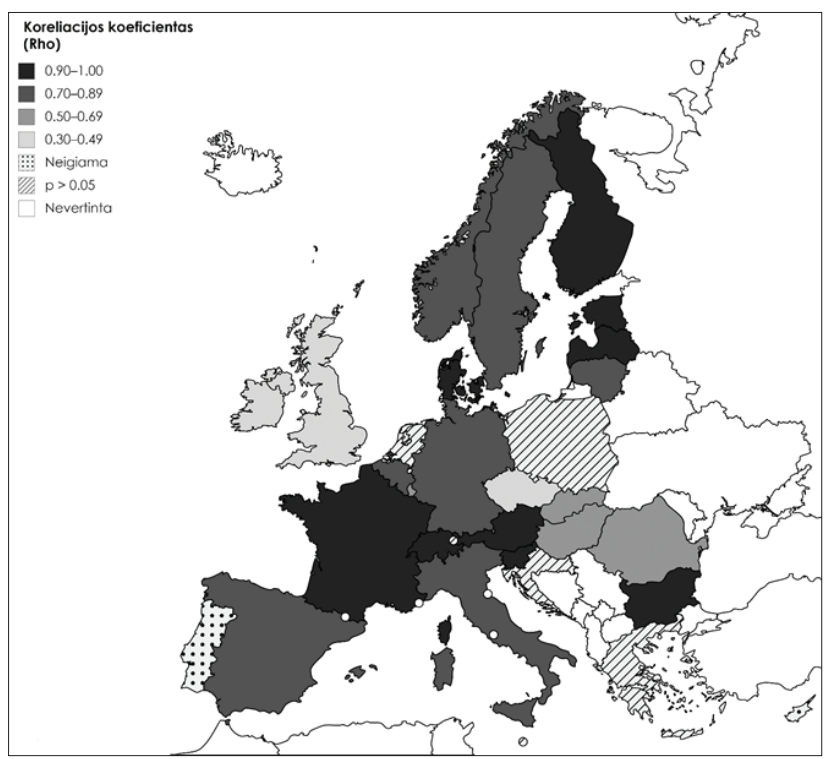

1 paveikslas. Ryšys tarp mirtingumo dèl savižudybių (X60-X84, TLK-10AM) ir išeminès širdies ligos (I20-I25, TLK-10AM). koreliavo taip pat 23 valstybėse (1 lentelè): 8 - labai stipriai; 10 - stipriai; 3 - vidutiniškai ir 2 - silpnai. Moterų rodikliai reikšmingai koreliavo 19 valstybių (1 lentelè): 4 - labai stipriai; 9 - stipriai ir 6 - vidutiniškai. Lietuvoje šis ryšys buvo stiprus tarp abiejų lyčių (Rho: bendrai - 0,798, p $\leq 0,001$; vyrai $-0,717, \mathrm{p} \leq 0,001$; moterys $-0,799, \mathrm{p} \leq 0,001$ ).

Statistiškai reikšminga priešinga koreliacija tarp mirtingumo dèl savižudybių ir mirtingumo dèl išeminès širdies ligos stebèta tik Portugalijoje ir Kipre. Tarp vyrų priešinga koreliacija stebetta taip pat ir Graikijoje, o tarp moterų rodiklių priešingo ryšio nestebèta. Pabrèžtina, kad analizuojant ryši tarp mirtingumo dèl kitų širdies ligų (I30-I51, TLK-10AM) ir dèl savižudybių nustatytas ženkliai silpnesnis tiesioginis ryšys (2 lentelè, 2 paveikslas): reikšminga tiesioginè koreliacija stebėta 13 valstybių, tarp vyrų -12 , tarp moterų -9 , o priešingas ryšys nustatytas netgi 7 valstybėse. Koreliacijos tarp mirtingumo dèl kitų širdies ligų ir savižudybių Lietuvoje nenustatyta (Rho: bendrai $--0,303, p=0,171$; vyrai $--0,386$, $\mathrm{p}=0,076$; moterys $-0,132, \mathrm{p}=0,558)(1,2$ pav. $)$.

Mirtingumas nuo išeminès širdies ligos ir savižudybių $<65$ metų amžiaus grupejje statistiškai reikšmingai tiesiogiai koreliavo 23 valstybėse (1 lentelè): 7 - labai stipriai; 9 - stipriai; 4 - vidutiniškai ir 3 - silpnai. Vyrų rodikliai statistiškai reikšmingai koreliavo taip pat 22 valstybèse (1 lentelè): 8 - labai stipriai; 7 - stipriai; 5 - vidutiniškai ir 2 silpnai. Moterų rodikliai reikšmingai koreliavo 19 valstybių (1 lentelè): 3 - labai stipriai; 12 - stipriai ir 4 -vidutiniškai. Lietuvoje šis ryšys buvo kur kas silpnesnis už daugeli ES valstybių tarp abiejų lyčių (Rho: bendrai - 0,462, p =0,03;

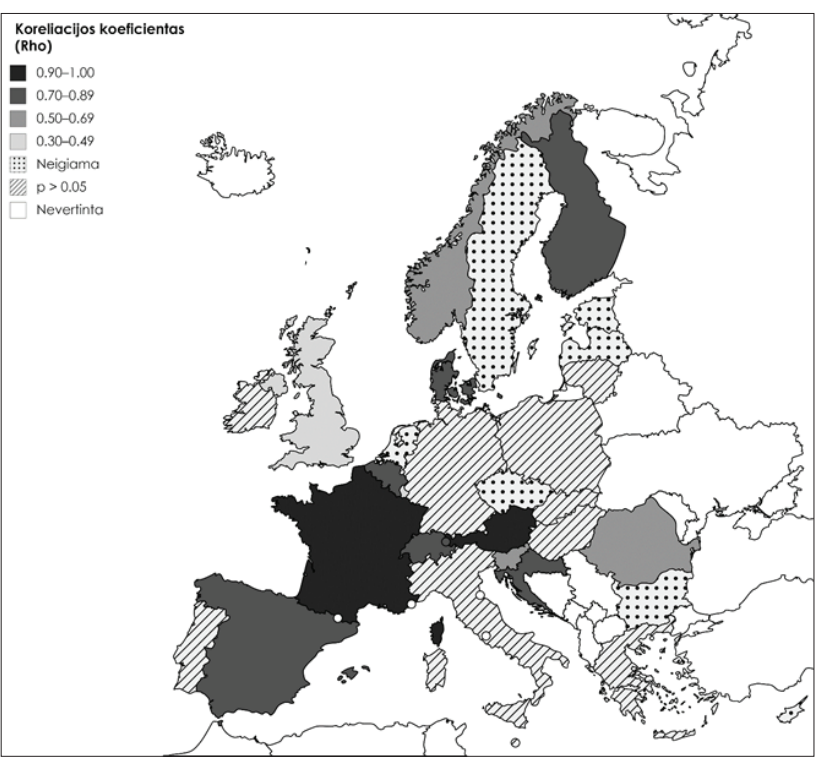

2 paveikslas. Ryšys tarp mirtingumo dèl savižudybių (X60-X84, TLK-10AM) ir kitų širdies ligų (I30-I52, TLK-10AM). 
1 lentelè. Ryšys tarp mirtingumo dèl savižudybių (X60-X84, TLK-10AM) ir išeminės širdies ligos (I20-I25, TLK-10AM) pagal lytị ir amžių (44-45 p.).

EU28 - Europos Sajunga (28 šalys); BE - Belgija; BG - Bulgarija; CZ - Čekija; DK - Danija; DE - Vokietija; EE - Estija; IE Airija; EL - Graikija; ES - Ispanija; FR - Prancūzija; HR - Kroatija; IT - Italija; CY - Kipras; LV - Latvija; LT - Lietuva; LU - Liuksemburgas; HU - Vengrija; MT - Malta; NL - Olandija; AT - Austrija; PL - Lenkija; PT - Portugalija; RO - Rumunija; SI

- Slovènija; SK - Slovakija; FI - Suomija; SE - Švedija; UK - Jungtinės Karalystės; NO - Norvegija; CH - Šveicarija.

\begin{tabular}{|c|c|c|c|c|c|c|c|c|c|c|c|}
\hline \multicolumn{3}{|c|}{$\begin{array}{l}\text { Bendrai } \\
\text { (I20-I25) }\end{array}$} & \multicolumn{2}{|c|}{$\begin{array}{c}\text { Vyrai } \\
\text { (I20-I25) }\end{array}$} & \multicolumn{2}{|c|}{$\begin{array}{l}\text { Moterys } \\
\text { (I20-I25) }\end{array}$} & \multicolumn{3}{|c|}{$\begin{array}{c}\text { Bendrai }<65 \text { m. } \\
(\text { I20-I25) }\end{array}$} & \multicolumn{2}{|c|}{$\begin{array}{c}\text { Vyrai <65 m. } \\
\text { (I20-I25) }\end{array}$} \\
\hline Šalis & Rho & p reikšmė & Rho & $\begin{array}{c}\mathbf{p} \\
\text { reikšmè }\end{array}$ & Rho & p reikšmė & Šalis & Rho & $\begin{array}{c}\mathbf{p} \\
\text { reikšmè }\end{array}$ & Rho & $\begin{array}{c}\mathrm{p} \\
\text { reikšmè }\end{array}$ \\
\hline EU28 & 0,862 & 0,000 & 0,820 & 0,000 & 0,955 & 0,000 & $\begin{array}{c}\text { EU2 } \\
8\end{array}$ & 0,727 & 0,003 & 0,697 & 0,006 \\
\hline BE & 0,852 & 0,000 & 0,863 & 0,000 & 0,710 & 0,001 & BE & 0,842 & 0,000 & 0,883 & 0,000 \\
\hline BG & 0,979 & 0,000 & 0,957 & 0,000 & 0,967 & 0,000 & BG & 0,927 & 0,000 & 0,933 & 0,000 \\
\hline $\mathbf{C Z}$ & 0,499 & 0,018 & 0,693 & 0,000 & 0,283 & 0,202 & $\mathrm{CZ}$ & 0,579 & 0,005 & 0,437 & 0,042 \\
\hline DK & 0,936 & 0,000 & 0,933 & 0,000 & 0,899 & 0,000 & DK & 0,860 & 0,000 & 0,855 & $\mathbf{0 , 0 0 0}$ \\
\hline DE & 0,854 & 0,000 & 0,881 & 0,000 & 0,843 & 0,000 & DE & 0,857 & 0,000 & 0,876 & 0,000 \\
\hline EE & 0,958 & 0,000 & 0,942 & 0,000 & 0,949 & 0,000 & EE & 0,937 & 0,000 & 0,947 & 0,000 \\
\hline IE & 0,470 & 0,027 & 0,428 & 0,047 & 0,337 & 0,125 & IE & 0,436 & 0,043 & 0,294 & 0,185 \\
\hline EL & $-0,403$ & 0,063 & $-0,446$ & 0,038 & $-0,361$ & 0,098 & EL & $-0,510$ & 0,015 & $-0,535$ & 0,010 \\
\hline $\mathbf{E S}$ & 0,813 & 0,000 & 0,852 & 0,000 & 0,636 & 0,001 & ES & 0,484 & 0,022 & 0,589 & 0,004 \\
\hline FR & 0,966 & 0,000 & 0,960 & 0,000 & 0,953 & 0,000 & FR & 0,926 & 0,000 & 0,901 & 0,000 \\
\hline HR & $-0,079$ & 0,788 & 0,209 & 0,473 & $-0,187$ & 0,522 & HR & 0,702 & 0,005 & 0,715 & 0,004 \\
\hline IT & 0,820 & 0,000 & 0,831 & 0,000 & 0,841 & 0,000 & IT & 0,706 & 0,000 & 0,628 & 0,003 \\
\hline CY & $-0,699$ & 0,011 & $-0,692$ & 0,013 & $-0,130$ & 0,688 & $\mathrm{CY}$ & $-0,434$ & 0,159 & $-0,476$ & 0,118 \\
\hline $\mathbf{L V}$ & 0,920 & 0,000 & 0,895 & $\mathbf{0 , 0 0 0}$ & 0,893 & $\mathbf{0 , 0 0 0}$ & LV & 0,771 & 0,000 & 0,743 & 0,000 \\
\hline LT & 0,798 & 0,000 & 0,717 & 0,000 & 0,799 & 0,000 & LT & 0,462 & $\mathbf{0 , 0 3 0}$ & 0,489 & 0,021 \\
\hline $\mathbf{L U}$ & 0,685 & 0,000 & 0,796 & $\mathbf{0 , 0 0 0}$ & 0,355 & 0,105 & $\mathbf{L U}$ & 0,698 & 0,000 & 0,671 & $\mathbf{0 , 0 0 1}$ \\
\hline HU & 0,686 & 0,000 & 0,739 & 0,000 & 0,567 & 0,006 & $\mathbf{H U}$ & 0,944 & 0,000 & 0,918 & 0,000 \\
\hline MT & $-0,397$ & 0,068 & $-0,414$ & 0,055 & 0,304 & 0,169 & MT & $-0,614$ & 0,002 & $-0,640$ & 0,001 \\
\hline NL & 0,028 & 0,903 & 0,038 & 0,867 & 0,302 & 0,172 & NL & $-0,315$ & 0,153 & $-0,508$ & 0,016 \\
\hline $\mathbf{A T}$ & 0,949 & 0,000 & 0,950 & 0,000 & 0,863 & 0,000 & $\mathbf{A T}$ & 0,983 & 0,000 & 0,963 & $\mathbf{0 , 0 0 0}$ \\
\hline PL & 0,091 & 0,704 & $-0,096$ & 0,686 & 0,406 & 0,076 & PL & $-0,061$ & 0,798 & $-0,201$ & 0,396 \\
\hline PT & $-0,460$ & 0,031 & $-0,518$ & 0,014 & $-0,422$ & 0,051 & PT & $-0,400$ & 0,065 & $-0,406$ & 0,061 \\
\hline RO & 0,698 & 0,002 & 0,662 & 0,004 & 0,861 & 0,000 & RO & 0,617 & 0,008 & 0,569 & $\mathbf{0 , 0 1 7}$ \\
\hline SI & 0,943 & 0,000 & 0,905 & 0,000 & 0,893 & 0,000 & SI & 0,890 & 0,000 & 0,913 & $\mathbf{0 , 0 0 0}$ \\
\hline SK & 0,631 & 0,003 & 0,696 & 0,001 & 0,515 & 0,020 & SK & 0,709 & 0,000 & 0,711 & 0,000 \\
\hline FI & 0,977 & 0,000 & 0,982 & $\mathbf{0 , 0 0 0}$ & 0,924 & 0,000 & FI & 0,975 & 0,000 & 0,962 & $\mathbf{0 , 0 0 0}$ \\
\hline SE & 0,888 & 0,000 & 0,892 & 0,000 & 0,671 & 0,001 & SE & 0,810 & 0,000 & 0,737 & $\mathbf{0 , 0 0 0}$ \\
\hline UK & 0,486 & 0,022 & 0,482 & 0,023 & 0,624 & $\mathbf{0 , 0 0 2}$ & UK & 0,225 & 0,315 & 0,268 & 0,229 \\
\hline NO & 0,733 & 0,000 & 0,789 & 0,000 & 0,016 & 0,942 & NO & 0,592 & 0,004 & 0,688 & 0,000 \\
\hline $\mathrm{CH}$ & 0,936 & 0,000 & 0,944 & 0,000 & 0,675 & 0,000 & $\mathrm{CH}$ & 0,946 & 0,000 & 0,956 & 0,000 \\
\hline
\end{tabular}




\begin{tabular}{|c|c|c|c|c|c|c|}
\hline \multicolumn{2}{|c|}{$\begin{array}{c}\text { Moterys }<65 \mathrm{~m} . \\
(\text { I20-I25) }\end{array}$} & \multicolumn{3}{|c|}{$\begin{array}{c}\text { Bendrai } \geq 65 \mathrm{~m} . \\
(\text { I20-I25) }\end{array}$} & \multicolumn{2}{|c|}{$\begin{array}{c}\text { Vyrai } \geq 65 \mathrm{~m} . \\
(\text { I20-I25) }\end{array}$} \\
\hline Rho & $\begin{array}{c}p \\
\text { reikšmė }\end{array}$ & Šalis & Rho & $\begin{array}{c}\mathbf{p} \\
\text { reikšmė }\end{array}$ & Rho & $\begin{array}{c}\mathbf{p} \\
\text { reikšmė }\end{array}$ \\
\hline 0,918 & 0,000 & EU28 & 0,965 & 0,000 & 0,996 & 0,000 \\
\hline 0,577 & 0,010 & $\overline{B E}$ & 0,840 & 0,000 & 0,824 & 0,000 \\
\hline 0,971 & 0,000 & BG & 0,977 & 0,000 & 0,944 & 0,000 \\
\hline 0,747 & 0,000 & $\mathrm{CZ}$ & 0,352 & 0,108 & 0,484 & 0,022 \\
\hline 0,844 & 0,000 & DK & 0,919 & $\mathbf{0 , 0 0 0}$ & 0,882 & 0,000 \\
\hline 0,806 & 0,000 & DE & 0,878 & 0,000 & 0,920 & 0,000 \\
\hline 0,915 & 0,000 & EE & 0,853 & 0,000 & 0,682 & 0,000 \\
\hline 0,257 & 0,248 & IE & 0,420 & 0,052 & 0,453 & 0,034 \\
\hline$-0,446$ & 0,038 & EL & 0,173 & 0,440 & 0,021 & 0,924 \\
\hline 0,157 & 0,486 & ES & 0,919 & 0,000 & 0,923 & $\mathbf{0 , 0 0 0}$ \\
\hline 0,863 & $\mathbf{0 , 0 0 0}$ & FR & 0,979 & 0,000 & 0,983 & 0,000 \\
\hline 0,443 & 0,113 & HR & $-0,332$ & 0,246 & $-0,086$ & 0,771 \\
\hline 0,832 & $\mathbf{0 , 0 0 0}$ & IT & 0,947 & 0,000 & 0,941 & $\mathbf{0 , 0 0 0}$ \\
\hline 0,497 & 0,101 & $\mathrm{CY}$ & $-0,469$ & 0,124 & $-0,294$ & 0,354 \\
\hline 0,726 & 0,000 & $\mathbf{L V}$ & 0,887 & 0,000 & 0,809 & 0,000 \\
\hline 0,385 & 0,077 & LT & 0,814 & $\mathbf{0 , 0 0 0}$ & 0,638 & 0,001 \\
\hline 0,617 & 0,002 & $\mathbf{L U}$ & 0,528 & 0,012 & 0,684 & 0,000 \\
\hline 0,940 & 0,000 & HU & 0,461 & 0,031 & 0,448 & $\mathbf{0 , 0 3 7}$ \\
\hline 0,167 & 0,469 & MT & 0,013 & 0,954 & 0,144 & 0,524 \\
\hline 0,099 & 0,663 & NL & 0,695 & 0,000 & 0,769 & 0,000 \\
\hline 0,885 & $\mathbf{0 , 0 0 0}$ & AT & 0,877 & 0,000 & 0,888 & $\mathbf{0 , 0 0 0}$ \\
\hline 0,757 & 0,000 & PL & 0,016 & 0,947 & $-0,172$ & 0,469 \\
\hline$-0,319$ & 0,148 & PT & $-0,434$ & 0,044 & $-0,476$ & 0,025 \\
\hline 0,808 & 0,000 & RO & 0,640 & 0,006 & 0,037 & 0,889 \\
\hline 0,806 & $\mathbf{0 , 0 0 0}$ & SI & 0,792 & 0,000 & 0,763 & $\mathbf{0 , 0 0 0}$ \\
\hline 0,615 & 0,004 & SK & 0,440 & 0,052 & 0,240 & 0,308 \\
\hline 0,853 & 0,000 & FI & 0,907 & 0,000 & 0,927 & 0,000 \\
\hline 0,534 & 0,011 & SE & 0,831 & 0,000 & 0,854 & 0,000 \\
\hline 0,140 & 0,533 & UK & 0,731 & 0,000 & 0,733 & 0,000 \\
\hline$-0,281$ & 0,205 & NO & 0,626 & 0,002 & 0,553 & 0,008 \\
\hline 0,814 & $\mathbf{0 , 0 0 0}$ & $\mathrm{CH}$ & 0,564 & 0,006 & 0,808 & 0,000 \\
\hline
\end{tabular}

ryšys stebėtas tik Graikijoje. Kitaip nei išeminès širdies ligos atveju, analizuojant ryšị tarp mirtingumo dèl kitų širdies ligų (I30-I51, TLK-10AM) ir dẻl savižudybių stebètas ženkliai silpnesnis tiesioginis ryšys (2 lentelè): reikšminga tiesioginè koreliacija nustatyta 11 valstybių, tarp vyrų -11 , tarp moterų -9 , o priešingas ryšys išaiškintas netgi 5 valstybèse. Tiesioginès koreliacijos tarp mirtingumo dèl kitų širdies ligų ir savižudybių Lietuvoje nenustatyta (Rho: bendrai $--0,352, \mathrm{p}=$ 0,108 ; vyrai $--0,425, p=0,048$; moterys $-0,164$, $\mathrm{p}=0,465)(1$ lentelè).

Mirtingumas nuo išeminès širdies ligos ir savižudybių $\geq 65$ metų amžiaus grupeje statistiškai reikšmingai tiesiogiai koreliavo 21 valstybėse (1 lentelè): 6 - labai stipriai; 9 - stipriai; 5 - vidutiniškai ir 1 - silpnai. Vyrų rodikliai statistiškai reikšmingai koreliavo taip pat 22 valstybèse (1 lentelè): 6 - labai stipriai; 9 - stipriai; 4 - vidutiniškai ir 3 -silpnai. Moterų rodikliai reikšmingai koreliavo 19 valstybių (1 lentelè): 4 - labai stipriai; 12 - stipriai; 2 - vidutiniškai ir 1 - silpnai. Lietuvoje šis ryšys buvo stiprus tarp moterų ir vidutinio stiprumo tarp vyru (Rho: bendrai $-0,814$, $\mathrm{p} \leq 0,001$; vyrai $-0,638, \mathrm{p}=0,001$; moterys $0,785, \mathrm{p} \leq 0,001)$.

Statistiškai reikšminga priešinga koreliacija tarp mirtingumo dèl savižudybių ir mirtingumo dèl išeminès širdies ligos $\geq 65$ metų amžiaus grupejje stebèta tik Portugalijoje. Tarp vyrų priešinga koreliacija taip pat nustatyta tik Portugalijoje, o tarp moterų priešingas ryšys išaiškintas tik Kroatijoje. Kitaip nei išeminès širdies ligos atveju, analizuojant ryšs tarp mirtingumo dèl kitų širdies ligu (I30-I51, TLK-10AM) ir dèl savižudybių stebètas ženkliai silpnesnis tiesioginis ryšys (2 lentelè): reikšminga tiesioginè koreliacija nustatyta 11 valstybių, tarp vyrų -10 , tarp moteru -9 , o priešingas ryšys nustatytas netgi 8 valstybėse. Lietuvoje tarp šių rodiklių statistiškai patikimos koreliacijos nenustatyta (Rho: bendrai $--0,342, p$ $=0,12$; vyrai $--0,32, \mathrm{p}=0,147$; moterys $--0,107$, $\mathrm{p}=0,636)(2$ lentelè).

Vertinant bendrą Europos Sajungos 28 valstybių mirtingumo dèl išeminès širdies ligos ir savižudybių rodiklių ryšį stebèta reikšminga teigiama koreliacija visuose analizuotuose pogrupiuose, o tiesioginis ryšys tarp kitų širdies ligų ir savižudybių rodiklių nebuvo nustatytas nei viename pogrupyje. 
2 lentelè. Ryšys tarp mirtingumo dèl savižudybių (X60-X84, TLK-10AM) ir kitų širdies ligų (I30-I52, TLK-10AM) pagal lytị ir amžių. (46-47 p.).

EU28 - Europos Sajunga (28 šalys); BE - Belgija; BG - Bulgarija; CZ - Čekija; DK - Danija; DE - Vokietija; EE - Estija; IE - Airija; EL - Graikija; ES - Ispanija; FR - Prancūzija; HR - Kroatija; IT - Italija; CY - Kipras; LV - Latvija; LT - Lietuva; LU - Liuksemburgas; HU - Vengrija; MT - Malta; NL - Olandija; AT - Austrija; PL - Lenkija; PT - Portugalija; RO - Rumunija; SI - Slovènija; SK - Slovakija; FI - Suomija; SE - Švedija; UK - Jungtinès Karalystès; NO - Norvegija; CH - Šveicarija.

\begin{tabular}{|c|c|c|c|c|c|c|c|c|c|c|c|}
\hline \multicolumn{3}{|c|}{$\begin{array}{l}\text { Bendrai } \\
\text { (I30-I51) }\end{array}$} & \multicolumn{2}{|c|}{$\begin{array}{c}\text { Vyrai } \\
\text { (I30-I51) }\end{array}$} & \multicolumn{2}{|c|}{$\begin{array}{l}\text { Moterys } \\
\text { (I30-I51) }\end{array}$} & \multicolumn{3}{|c|}{$\begin{array}{c}\text { Bendrai < } 65 \text { m. } \\
(\text { I30-I51) }\end{array}$} & \multicolumn{2}{|c|}{$\begin{array}{c}\text { Vyrai <65 m. } \\
\text { (I30-I51) }\end{array}$} \\
\hline Šalis & Rho & $\begin{array}{c}\text { p } \\
\text { reikšmè }\end{array}$ & Rho & $\begin{array}{c}\mathbf{p} \\
\text { reikšmè }\end{array}$ & Rho & $\begin{array}{c}\text { p } \\
\text { reikšmè }\end{array}$ & Šalis & Rho & $\begin{array}{c}\mathbf{p} \\
\text { reikšmè }\end{array}$ & Rho & $\begin{array}{c}\mathbf{p} \\
\text { reikšmė }\end{array}$ \\
\hline EU28 & $-0,357$ & 0,254 & $-0,406$ & 0,191 & $-0,588$ & 0,045 & EU28 & $-0,126$ & 0,697 & $-0,098$ & 0,762 \\
\hline $\mathrm{BE}$ & 0,738 & 0,002 & 0,736 & 0,002 & 0,445 & 0,097 & $\mathrm{BE}$ & 0,683 & 0,005 & 0,825 & 0,000 \\
\hline $\mathrm{BG}$ & $-0,935$ & $\mathbf{0 , 0 0 0}$ & $-0,907$ & 0,000 & $-0,908$ & $\mathbf{0 , 0 0 0}$ & BG & $-0,864$ & 0,000 & $-0,865$ & $\mathbf{0 , 0 0 0}$ \\
\hline $\mathrm{CZ}$ & $-0,775$ & $\mathbf{0 , 0 0 0}$ & $-0,746$ & $\mathbf{0 , 0 0 0}$ & $-0,759$ & $\mathbf{0 , 0 0 0}$ & $\mathrm{CZ}$ & $-0,323$ & 0,143 & $-0,322$ & 0,143 \\
\hline DK & 0,759 & 0,000 & 0,748 & 0,000 & 0,748 & 0,000 & $\overline{D K}$ & 0,674 & 0,001 & 0,683 & 0,001 \\
\hline $\mathrm{DE}$ & $-0,429$ & 0,337 & $-0,036$ & 0,939 & $-0,055$ & 0,908 & $\mathrm{DE}$ & $-0,468$ & 0,289 & $-0,464$ & 0,294 \\
\hline $\mathrm{EE}$ & $-0,857$ & 0,000 & $-0,824$ & 0,000 & $-0,883$ & 0,000 & $\mathrm{EE}$ & 0,379 & 0,082 & 0,325 & 0,140 \\
\hline IE & 0,387 & 0,102 & 0,392 & 0,097 & 0,128 & 0,601 & IE & 0,405 & 0,086 & 0,442 & 0,058 \\
\hline EL & $-0,224$ & 0,316 & $-0,397$ & 0,068 & $-0,102$ & 0,653 & EL & $-0,060$ & 0,792 & 0,143 & 0,525 \\
\hline $\mathrm{ES}$ & 0,821 & $\mathbf{0 , 0 0 0}$ & 0,852 & 0,000 & 0,633 & 0,002 & $\mathrm{ES}$ & 0,452 & $\mathbf{0 , 0 3 5}$ & 0,530 & 0,011 \\
\hline FR & 0,980 & $\mathbf{0 , 0 0 0}$ & 0,971 & $\mathbf{0 , 0 0 0}$ & 0,944 & $\mathbf{0 , 0 0 0}$ & FR & 0,929 & $\mathbf{0 , 0 0 0}$ & 0,867 & $\mathbf{0 , 0 0 0}$ \\
\hline HR & 0,898 & 0,000 & 0,763 & 0,001 & 0,802 & 0,001 & HR & 0,759 & 0,002 & 0,746 & 0,002 \\
\hline IT & 0,273 & 0,367 & 0,281 & 0,352 & 0,526 & 0,065 & IT & 0,036 & 0,907 & $-0,201$ & 0,509 \\
\hline $\mathrm{CY}$ & $-0,727$ & $\mathbf{0 , 0 0 7}$ & $-0,594$ & 0,042 & $-0,312$ & 0,324 & $\mathrm{CY}$ & $-0,727$ & 0,007 & $-0,671$ & 0,017 \\
\hline LV & $-0,917$ & 0,000 & $-0,869$ & 0,000 & $-0,938$ & $\mathbf{0 , 0 0 0}$ & LV & $-0,535$ & 0,015 & $-0,596$ & 0,006 \\
\hline $\mathrm{LT}$ & $-0,303$ & 0,171 & $-0,386$ & 0,076 & $-0,132$ & 0,558 & LT & $-0,352$ & 0,108 & $-0,425$ & 0,048 \\
\hline LU & 0,441 & 0,046 & 0,453 & 0,039 & 0,125 & 0,590 & LU & 0,442 & 0,045 & 0,588 & 0,005 \\
\hline $\mathrm{HU}$ & $-0,243$ & 0,275 & $-0,440$ & 0,041 & $-0,103$ & 0,649 & $\mathrm{HU}$ & 0,365 & 0,095 & 0,271 & 0,222 \\
\hline MT & $-0,398$ & 0,067 & $-0,367$ & 0,093 & 0,237 & 0,289 & MT & $-0,160$ & 0,478 & $-0,131$ & 0,562 \\
\hline NL & $-0,783$ & 0,013 & $-0,217$ & 0,576 & $-0,753$ & 0,019 & NL & $-0,983$ & $\mathbf{0 , 0 0 0}$ & $-0,950$ & 0,000 \\
\hline AT & 0,902 & $\mathbf{0 , 0 0 0}$ & 0,846 & $\mathbf{0 , 0 0 0}$ & 0,886 & $\mathbf{0 , 0 0 0}$ & AT & 0,915 & $\mathbf{0 , 0 0 0}$ & 0,940 & 0,000 \\
\hline PL & 0,191 & 0,574 & 0,245 & 0,467 & $-0,661$ & $\mathbf{0 , 0 2 7}$ & PL & 0,245 & 0,467 & 0,255 & 0,450 \\
\hline PT & $-0,411$ & 0,057 & $-0,419$ & 0,052 & $-0,336$ & 0,126 & PT & $-0,329$ & 0,135 & $-0,286$ & 0,197 \\
\hline RO & 0,614 & 0,009 & 0,434 & 0,081 & 0,835 & $\mathbf{0 , 0 0 0}$ & $\mathrm{RO}$ & $-0,611$ & 0,009 & $-0,567$ & 0,018 \\
\hline SI & 0,512 & 0,015 & 0,580 & 0,005 & 0,316 & 0,152 & SI & 0,829 & $\mathbf{0 , 0 0 0}$ & 0,771 & $\mathbf{0 , 0 0 0}$ \\
\hline SK & $-0,397$ & 0,083 & $-0,351$ & 0,130 & $-0,434$ & 0,056 & SK & $-0,335$ & 0,149 & $-0,437$ & 0,054 \\
\hline FI & 0,759 & 0,000 & 0,696 & 0,001 & 0,740 & $\mathbf{0 , 0 0 0}$ & FI & 0,321 & 0,168 & 0,181 & 0,446 \\
\hline $\mathrm{SE}$ & $-0,664$ & 0,001 & $-0,673$ & 0,001 & $-0,526$ & 0,012 & $\mathrm{SE}$ & 0,680 & 0,000 & 0,539 & $\mathbf{0 , 0 1 0}$ \\
\hline UK & 0,442 & 0,040 & 0,493 & 0,020 & 0,586 & 0,004 & UK & 0,235 & 0,292 & 0,208 & 0,354 \\
\hline $\mathrm{NO}$ & 0,586 & 0,004 & 0,709 & 0,000 & $-0,138$ & 0,540 & $\mathrm{NO}$ & 0,504 & 0,017 & 0,646 & 0,001 \\
\hline $\mathrm{CH}$ & 0,871 & $\mathbf{0 , 0 0 0}$ & 0,886 & 0,000 & 0,449 & 0,041 & $\mathrm{CH}$ & 0,929 & $\mathbf{0 , 0 0 0}$ & 0,957 & 0,000 \\
\hline
\end{tabular}




\begin{tabular}{|c|c|c|c|c|c|c|c|c|}
\hline \multicolumn{2}{|c|}{$\begin{array}{c}\text { Moterys }<65 \text { m. } \\
\text { (I30-I51) }\end{array}$} & \multicolumn{3}{|c|}{$\begin{array}{c}\text { Bendrai } \geq 65 \mathrm{~m} \\
\quad(\mathrm{I30}-\mathrm{I51})\end{array}$} & \multicolumn{2}{|c|}{$\begin{array}{c}\text { Vyrai } \geq 65 \text { m. } \\
\text { (I30-I51) }\end{array}$} & \multicolumn{2}{|c|}{$\begin{array}{c}\text { Moterys } \geq 65 \text { m. } \\
\text { (I30-I51) }\end{array}$} \\
\hline Rho & $\begin{array}{c}\mathbf{p} \\
\text { reikšmė }\end{array}$ & Šalis & Rho & $\begin{array}{c}\text { p } \\
\text { reikšmė }\end{array}$ & Rho & $\begin{array}{c}\mathbf{p} \\
\text { reikšmė }\end{array}$ & Rho & $\begin{array}{c}\mathrm{p} \\
\text { reikšmė }\end{array}$ \\
\hline$-0,585$ & 0,046 & EU28 & $-0,706$ & 0,010 & $-0,755$ & 0,005 & $-0,699$ & 0,011 \\
\hline 0,212 & 0,449 & $\mathrm{BE}$ & 0,661 & 0,007 & 0,640 & 0,010 & 0,626 & $\mathbf{0 , 0 1 3}$ \\
\hline$-0,891$ & 0,000 & $\mathrm{BG}$ & $-0,904$ & 0,000 & $-0,897$ & $\mathbf{0 , 0 0 0}$ & $-0,905$ & $\mathbf{0 , 0 0 0}$ \\
\hline$-0,008$ & 0,972 & $\mathrm{CZ}$ & $-0,822$ & $\mathbf{0 , 0 0 0}$ & $-0,781$ & $\mathbf{0 , 0 0 0}$ & $-0,841$ & $\mathbf{0 , 0 0 0}$ \\
\hline 0,590 & 0,005 & $\overline{\mathrm{DK}}$ & 0,784 & 0,000 & 0,642 & 0,002 & 0,825 & $\mathbf{0 , 0 0 0}$ \\
\hline$-0,286$ & 0,535 & $\overline{\mathrm{DE}}$ & 0,179 & 0,702 & 0,643 & 0,119 & 0,214 & 0,645 \\
\hline 0,485 & 0,022 & $\mathrm{EE}$ & $-0,867$ & 0,000 & $-0,710$ & $\mathbf{0 , 0 0 0}$ & $-0,877$ & 0,000 \\
\hline 0,003 & 0,991 & IE & 0,444 & 0,057 & 0,379 & 0,109 & 0,301 & 0,210 \\
\hline$-0,315$ & 0,153 & $\overline{E L}$ & 0,154 & 0,493 & 0,050 & 0,826 & 0,248 & 0,266 \\
\hline 0,211 & 0,346 & ES & 0,925 & $\mathbf{0 , 0 0 0}$ & 0,896 & $\mathbf{0 , 0 0 0}$ & 0,847 & $\mathbf{0 , 0 0 0}$ \\
\hline 0,827 & $\mathbf{0 , 0 0 0}$ & FR & 0,961 & 0,000 & 0,976 & $\mathbf{0 , 0 0 0}$ & 0,938 & $\mathbf{0 , 0 0 0}$ \\
\hline 0,268 & 0,355 & HR & 0,895 & 0,000 & 0,726 & 0,003 & 0,811 & $\mathbf{0 , 0 0 0}$ \\
\hline 0,365 & 0,221 & IT & 0,660 & 0,014 & 0,538 & 0,058 & 0,642 & 0,018 \\
\hline$-0,308$ & 0,330 & CY & $-0,657$ & 0,020 & $-0,580$ & 0,048 & $-0,306$ & 0,333 \\
\hline$-0,108$ & 0,652 & $\overline{L V}$ & $-0,910$ & $\mathbf{0 , 0 0 0}$ & $-0,751$ & 0,000 & $-0,841$ & 0,000 \\
\hline$-0,164$ & 0,465 & LT & $-0,342$ & 0,120 & $-0,320$ & 0,147 & $-0,107$ & 0,636 \\
\hline 0,183 & 0,426 & $\begin{array}{l}\mathrm{LU} \\
\end{array}$ & 0,142 & 0,540 & 0,381 & 0,089 & $-0,206$ & 0,369 \\
\hline 0,677 & 0,001 & $\mathrm{HU}$ & $-0,320$ & 0,146 & $-0,536$ & $\mathbf{0 , 0 1 0}$ & $-0,273$ & 0,219 \\
\hline$-0,322$ & 0,154 & MT & 0,079 & 0,728 & 0,046 & 0,840 & 0,100 & 0,667 \\
\hline$-0,929$ & 0,000 & $\mathrm{NL}$ & $-0,711$ & $\mathbf{0 , 0 3 2}$ & $-0,400$ & 0,286 & $-0,661$ & 0,053 \\
\hline 0,764 & 0,000 & AT & 0,896 & 0,000 & 0,857 & $\mathbf{0 , 0 0 0}$ & 0,908 & $\mathbf{0 , 0 0 0}$ \\
\hline$-0,261$ & 0,437 & PL & $-0,164$ & 0,631 & $-0,009$ & 0,979 & $-0,736$ & 0,010 \\
\hline$-0,261$ & 0,240 & PT & $-0,346$ & 0,115 & $-0,374$ & 0,086 & $-0,280$ & 0,208 \\
\hline 0,273 & 0,289 & $\mathrm{RO}$ & 0,613 & 0,009 & 0,234 & 0,366 & 0,777 & 0,000 \\
\hline 0,894 & $\mathbf{0 , 0 0 0}$ & SI & 0,305 & 0,167 & 0,409 & 0,059 & 0,215 & 0,337 \\
\hline$-0,074$ & 0,758 & SK & $-0,443$ & 0,050 & $-0,338$ & 0,145 & $-0,482$ & $\mathbf{0 , 0 3 2}$ \\
\hline 0,521 & 0,018 & FI & 0,609 & 0,004 & 0,540 & 0,014 & 0,647 & 0,002 \\
\hline 0,438 & 0,041 & $\overline{\mathrm{SE}}$ & $-0,642$ & 0,001 & $-0,582$ & 0,004 & $-0,623$ & 0,002 \\
\hline 0,257 & 0,248 & UK & 0,709 & 0,000 & 0,717 & $\mathbf{0 , 0 0 0}$ & 0,843 & $\mathbf{0 , 0 0 0}$ \\
\hline$-0,123$ & 0,586 & $\mathrm{NO}$ & 0,442 & $\mathbf{0 , 0 3 9}$ & 0,426 & 0,048 & 0,316 & 0,151 \\
\hline 0,673 & 0,001 & $\mathrm{CH}$ & 0,346 & 0,125 & 0,719 & $\mathbf{0 , 0 0 0}$ & 0,201 & 0,381 \\
\hline
\end{tabular}

\section{Aptarimas}

Vis dažniau akcentuojamas ryšys tarp psichikos sveikatos ir išeminès širdies ligos. Remiantis Gan ir kt. metaanalize [6], kurioje apibendrinta 30 tyrimų, atliktų nuo 1994 iki 2014 metų, pacientams, sergantiems depresija, net 30 proc. padidejja tikimybe susirgti koronarine širdies liga. Pacientams, persirgusiems miokardo infarktu ir susirgusiems depresija, yra didesnè ūmaus koronarinio sindromo pasikartojimo rizika, kas susiję ir su didesniu mirtingumu [7]. Šị ryši iš dalies bandoma pagrịsti argumentuojant, kad depresija sergantys asmenys dažiau ima rūkyti, vartoti didelius alkoholio kiekius, yra mažiau fiziškai aktyvūs, taip pat turi padidejusị kraujo spaudimą, yra nutukę [5].

Psichikos sveikatos sutrikimų nulemtą išaugusią koronarinès širdies ligos riziką bandoma paaiškinti keliais mechanizmais. Visų pirma psichikos sutrikimai neigiamai veikia autonominę nervų sistemą, dèl kurios tonuso sumažejimo gali atsirasti širdies ritmo sutrikimai, kraujospūdžio pakylimai, QT intervalo pokyčiai [8]. Taip pat akcentuojamas galimas poveikis per pagumburio-hipofizès ašies reguliavimo sutrikimus, uždegiminius procesus, lipidų koncentracijos pokyčius, oksidacinį stresą ir padidèjusi trombocitų aktyvumą [9]. Be abejo, psichikos ligos dažnai susijusios su kartu pasireiškiančiais elgesio pokyčiais (tokie kaip rūkymas, alkoholizmas, mažesnis fizinis aktyvumas, daug riebalu turinti dieta), kurie didina širdies-kraujagysliu sistemos ligų atsiradimo riziką [10].

Pastaruoju metu vis labiau gilinamasi i bendrą depresijos ir kraujagyslių sistemos ligų uždegiminę patogenezès grandį. Depresijos metu igimto imuniteto ląstelès ima sintetinti uždegimą sukeliančius citokinus, kurie nulemia tolesnę užde- 
giminių baltymų sintezę. Taigi, vystosi lètinis uždegimas, kuris apsprendžia padidintą sergamumo ir mirtingumo riziką nuo širdies ir kraujagyslių ligų [11].

Augantis psichikos sveikatos sutrikimų dažnis ir jų keliama rizika kardiovaskulinių ligų vystymuisi lemia, kad vis didesnè populiacijos dalis vienu metu turi ir psichikos sveikatos sutrikimų, ir širdies-kraujagyslių sistemos ligu [12]. Tai susiję ne tik su prastesne gyvenimo kokybe, tačiau ir su didžiule ekonomine našta. Europos kardiologų draugijos atliktoje apžvalgoje akcentuojama, kad žmonès, turintys abiejų grupių sutrikimus, žymiai dažniau tampa nedarbingi: sergant išemine širdies liga santykinè rizika tapti nedarbingiems vyrams $-2,84$ ir moterims $-2,83$, o turint psichikos sveikatos sutrikimą vyrams $-5,13$ ir moterims $-6,08$. Turint abu sutrikimus rizikos santykis išauga daugiau nei kelis kartus ir vyrams pakyla iki 18,38, o moterims iki 25,58 [13].

Psichikos sveikatos reikšmė išeminei širdies ligai išsivystyti skiriasi tarp lyčių bei skirtingų amžiaus grupių. Jungtinių Amerikos Valstijų mokslininkai, apžvelgdami ṣ̌ komorbidiškumą, atkreipia dèmesị, kad būtent jaunesnèms nei 55 metų moterims depresija buvo reikšmingas išeminès širdies ligos ir mirtingumo nuo jos prognostinis veiksnys. Tokio pat amžiaus vyrams bei vyresnèms nei 55 metai moterims šis ryšys nustatytas silpnesnis [14]. Mūsų atliktame tyrime ženklių skirtumų, susijusių su amžiumi bei lytimi, nestebèta - ryšys tarp mirtingumo dèl savižudybių ir išeminès širdies ligos reikšmingai nesiskyrè tarp abiejų lyčių ir abiejų amžiaus grupių. Šis skirtumas bent iš dalies susijęs su skirtingai pasirinktais amžiaus intervalais: anksčiau minėtame straipsnyje akcentuojama 55 metų amžiaus riba, kuri dažnai susijusi su perimenopauziniu laikotarpiu, kai mūsų tyrime pasirinkta iki 65 metų amžiaus grupè.

Tolesnè analizè nurodè, jog mirtingumas dèl savižudybių ir išeminès širdies ligos reikšmingai tiesiogiai koreliavo visuose (pagal amžių ir pagal lytį) tirtuose pogrupiuose. Atvirkščiai, šios tendencijos nestebejome vertinant ryši tarp mirtingumo dẻl savižudybių ir kitų širdies ligų. Šiuo atveju vertinant bendrą ES28 mirtingumo rodikli tiesioginis ryšys nebuvo nustatytas nè viename iš tirtų pogrupių. Taigi vertetų atkreipti dèmesį, kad ženkliai stipresnè sąsaja yra būtent tarp išeminès širdies ligos ir savižudybių.

Ryši tarp išeminès širdies ligos ir psichikos sveikatos parodo ir teigiamas gydomo psichikos sutrikimo efektas esamai širdies ligai. Carney ir kt. [15] atliktame tyrime buvo tirti žmonès, sergantys depresija ir persirgę išemine širdies liga. Tyrimo metu buvo nustatyta, kad asmenų, sẻkmingai besigydančių depresiją, išgyvenamumas po koronarinès širdies ligos buvo reikšmingai didesnis nei tiriamujų, kurie depresijos nesigydè ar gydèsi nesèkmingai.

\section{Išvados}

Nustatytas reikšmingas tiesioginis ryšys tarp mirtingumo dèl išeminès širdies ligos (I20-I25, TLK-10AM) ir savižudybių (X60-X84, TLK-10AM) daugelyje Europos Sajungos valstybių bei išlieka reikšmingas tiek tarp vyrų ir moterų bei asmenų jaunesnių ir vyresnių nei 65 metai. Tikètina, kad psichinès sveikatos įtaka šioms dviem problemoms yra labai reikšminga. Ypač Lietuvoje šių problemų didžiulis mastas ir jų reikšmingas ryšys reikalauja efektyvesnių psichinès sveikatos priežiūros metodų plètros.

\section{Literatūra}

1. Cardiovascular diseases statistics. Europos Sajungos statistikos tarnybos duomenys (EUROSTAT) [žiūrèta 2018-11-22]. Prieiga per internetą: $<$ https://ec.europa.eu/eurostat/statistics-explained/index.php/Cardiovascular_diseases_statistics\#Deaths from_cardiovascular_diseases>.

2. Mirties priežasčių registras. Mirties priežastys 2017. Higienos instituto Sveikatos informacijos centras. ISSN 1392-9186 [žiūrèta 2018-11-22]. Prieiga per internetą: < http://hi.lt/uploads/ pdf/leidiniai/Statistikos/Mirties_priezastys/Mirties_priezastys_2017.pdf>.

3. Organization WH. World Health Statistics 2017: Monitoring Health for the Sustainable Development Goals (SDGs): World Health Organization, 2017; 61.

4. Bertolote JM, Fleischmann A. Suicide and psychiatric diagnosis: a worldwide perspective. World Psychiatry 2002; 1(3):1815 .

5. De Hert M, Detraux J, Vancampfort D. The intriguing relationship between coronary heart disease and mental disorders. Dialogues Clin Neurosci 2018; 20(1):31-40.

6. Gan Y, Gong Y, Tong X, Sun H, Cong Y, Dong X. et al. Depression and the risk of coronary heart disease: a metaanalysis of prospective cohort studies. BMC Psychiatry 2014;14:371. https://doi.org/10.1186/s12888-014-0371-z

7. Sin NL, Kumar AD, Gehi AK, Whooley MA. Direction of association between depressive symptoms and lifestyle behaviors in patients with coronary heart disease: the heart and soul study. Ann Behav Med 2016; 50(4):523-32.

https://doi.org/10.1007/s12160-016-9777-9

8. Gianaros PJ, Wager TD. Brain body pathways linking psychological stress and physical health. Curr Dir Psychol Sci 2015; 24(4):313-21.

https://doi.org/10.1177/0963721415581476

9. Henderson DC, Vincenzi B, Andrea NV, Ulloa M, Copeland PM. Pathophysiological mechanisms of increased cardiometabolic risk in people with schizophrenia and other severe mental illnesses. Lancet Psychiatry 2015; 2(5):452-64.

https://doi.org/10.1016/S2215-0366(15)00115-7

10. Cohen BE, Edmondson D, Kronish IM. State of the art review: depression, stress, anxiety, and cardiovascular disease. Am J 
Hypertens 2015; 28(11):1295-302.

https://oi.org/10.1093/ajh/hpv047

11. Penninx BW. Depression and cardiovascular disease: epidemiological evidence on their linking mechanisms. Neurosci Biobehav Rev 2017; 74(Pt B):277-86.

12. Carney RM, Freedland KE. Depression and coronary heart disease. Nat Rev Cardiol 2017;14(3):145-55.

https://doi.org/10.1038/nrcardio.2016.181

13. Luscher TF. Epidemiology of cardiovascular disease: the new ESC atlas and beyond. Eur Heart J 2018; 39(7):489-92. https://doi.org/10.1093/eurheartj/ehy070

14. Mehta PK, Wei J, Wenger NK. Ischemic heart disease in women: a focus on risk factors. Trends Cardiovasc Med 2015;25(2):140-51. https://doi.org/10.1016/j.tcm.2014.10.005

15. Carney RM, Freedland KE, Steinmeyer BC, Rubin EH, Rich MW. Clinical predictors of depression treatment outcomes in patients with coronary heart disease. J Psychosom Res 2016;88:36-41.

https://doi.org/10.1016/j.jpsychores.2016.07.011

\section{THE LINK BETWEEN ISCHEMIC HEART DISEASE AND THE PREVALENCE OF SUICIDE IN EUROPEAN UNION}

P.Navickas, L.Lukavičiūtè, P.Šerpytis, A.Benošis, R.Šerpytis, K.Daškevičius, A.Navickas

Key words: ischemic heart disease, suicide, European Union, gender, age.

Summary

Objective. The purpose of this analysis was to evaluate the link between mortality due to suicides and cardiovascular disease in the European Union (hereafter - EU).

Methods. An epidemiological analytical study to assess mortality due to ischemic heart disease (I20-I25, ICD-10AM), other forms of heart disease (I30-I52, ICD-10AM) and mortality due to suicide (X60-X84, ICD-10AM) has been conducted. The study encompassed data during the years 1994 - 2015 from 30 (EU28, Norway, Switzerland) European countries. Data were also evaluated by age group: $<65$ years and $\geq 65$ years and by gender.
Results. A statistically significant positive correlation coefficient between mortality rates due to suicide and due to ischaemic heart disease was found in 23 countries: in 9 the correlation was very strong; in 7 - strong, in 4 - moderate and in 3 -weak. Among men a statistically significant positive correlation coefficient between mortality rates due to suicide and due to ischaemic heart disease also found in 23 countries: in 8 - very strong; in 10 - strong, in 3 - moderate and in 2 - weak. Likewise, the analysis amongst women alone showed a statistically significant positive correlation in 19 countries: in 4 - very strong; in 9 - strong and in 6 - moderate. In the patient group aged under 65 years a statistically significant positive correlation could be seen in 23 countries: in 7 - very strong; in 9 - strong; in 4 - moderate and in 3 - weak. While in respondents group above the age of 65 years a statistically significant positive correlation was found in 21 countries: in 6 - very strong; in 9 -strong; in 5-moderate in 1 weak. In Lithuania a statistically significant positive correlation was found among both genders (Rho: total $-0.798, \mathrm{p} \leq 0.001$; men$0.717, \mathrm{p} \leq 0.001$; women $-0.799, \mathrm{p} \leq 0.001)$ and both age groups $(<65$ years: total $-0.462, \mathrm{p}=0.03$; men $-0.489, \mathrm{p}=0.021$; women -0.385 , $\mathrm{p}=0.077$; $\geq 65$ years: total $-0.814, \mathrm{p} \leq 0.001$; men- $0.638, \mathrm{p}=0.001$; women- $0.785, \mathrm{p} \leq 0.001)$. By contrast, such a strong positive correlation was not found between death rates due to suicide and other heart diseases: a statistically significant positive correlation was found in 13 countries, among men in -12 , among women in -9 , a negative correlation was found in 7 countries.

Conclusions. Our study confirms that there is a strong relationship between ischaemic heart disease and suicides in $\mathrm{Eu}-$ ropean countries. This correlation is also statistically significant and strong when analysed separately by gender and in different age groups. We believe that our findings represent the dualism of psychological distress or mental illness as a contributor to or resulting from a cardiovascular disorder. Particularly in Lithuania, the large scale of these health problems and the significant correlation between them requires a more effective development of mental health care methods.

Correspondence to: alvydas.navickas@mf.vu.lt

Gauta 2019-01-15 